WILLIAM JAMES 
This page intentionally left blank 


\title{
WILLIAM JAMES
}

\section{HIS LIFE AND THOUGHT}

\author{
GERALD E. MYERS
}

080

YALE UNIVERSITY PRESS

NEW HAVEN AND LONDON 
Copyright 01986 by Yale University. All rights reserved.

This book may not be reproduced, in whole or in part, in any form (beyond that copying permitted by Sections 107 and 108 of the U.S. Copyright Law and except by reviewers for the public press), without written permission from the publishers.

Designed by Sally Harris.

Set in Meridien type by The Composing Room of Michigan, Inc.

Printed in the United States of America

Library of Congress Cataloging-in-Publication Data

Myers, Gerald E. (Gerald Eugene), 1923-

William James, his life and thought.

Bibliography: $p$.

Includes index.

1. James, William, 1842-1910. I. Title.

B945.J24M94 $1986 \quad 191[\mathrm{~B}] \quad 85-26288$

ISBN 0-300-08917-1

Acknowledgment is made for permission to quote from the following:

Two letters from William James to Robert Underwood Johnson, by permission of the American Academy and Institute of Arts and Letters.

A letter from William James to Elizabeth Glendower Evans, by permission of the Schlesinger Library, Radcliffe College.

A letter from John Dewey to Scudder Klyce, by permission of the Center for Dewey Studies, Southern Illinois University at Carbondale.

Materials from the Ralph Barton Perry Papers, by permission of Bernard Perry and of the Harvard University Archives.

Materials from the William James Papers, by permission of Alexander R. James and of the Houghton Library, Harvard University.

Ralph Barton Perry, The Thought and Character of William James (Boston: Little, Brown and Company, 1935), by permission of the publisher.

$\begin{array}{llllllll}10 & 9 & 8 & 7 & 6 & 5 & 4 & 3\end{array}$


TO CURT AND MARTHA 
This page intentionally left blank 